\title{
Imagens da mulher na revista Vida Capichaba (1940-1949)
}

\author{
Cecília Nunes da Silva* \\ Felipe Quintão Almeida** \\ Ivan Marcelo Gomes ${ }^{* * *}$
}

\begin{abstract}
Resumo: Investiga imagens da mulher na revista Vida Capichaba, periódico de publicação quinzenal que circulou, no Estado do Espírito Santo, entre as décadas de 1920 e 1950. Tem como foco as edições publicadas entre os anos de 1940 e 1949. Analisa os imperativos sociais destinados à formação da mulher capixaba. Conclui que esses imperativos eram ambivalentes (ao mesmo tempo conservadores e subversivos), tendo a prática esportiva, e a moda a ela associada, papel importante na construção de novas imagens e sentidos do feminino.
\end{abstract}

Palavras chave: Mulher. Moda. Esportes.

\section{INTRODUÇÃo}

Este artigo, na esteira de Goellner (2003), diz sobre imagens da mulher na revista Vida Capichaba. A reflexão empreendida dialoga, por um lado, com um referencial que se ocupou em narrar a história das mulheres (PERROT, 2008; SANT'ANNA, 1995, DEL PRIORE, 2004; LIPOVETSKY, 2000; ALBINO; VAZ, 2008). e, por outro lado, com uma literatura que enfatiza essa história na sua relação com a moda e/ou com o esporte. (LIPOVETSKY, 1989, GOELLNER, 2003, 2008; LAVER, 1989; FEIJÃO, 1989, 2011; BARTHES, 1967; SOARES, 2010).

\footnotetext{
"Mestranda do Programa de Pós Graduação em Educação Física. Centro de Educação Física e Desportos da Universidade Federal do Espírito Santo (CEFD/UFES). Vitória, ES, Brasil. Email: ceciliaef@hotmail.com.

"Departamento de Ginástica. Centro de Educação Física e Desportos da Universidade Federal do Espírito Santo (CEFD/UFES). Vitória, ES, Brasil. UFES/UFSC. E-mail: fqalmeida@hotmail.com.

"'Departamento de Ginástica. Centro de Educação Física e Desportos da Universidade Federal do Espírito Santo (CEFD/UFES). Vitória, ES, Brasil. E-mail: ivanmgomes@hotmail.com.
} 
Para empreender a investigação, duas decisões metodológicas foram tomadas. A primeira delas, temporal, elegeu os anos de 1940 (1941-1949) como o período em que nossas análises estariam concentradas, por acreditar que muitas mudanças sociais, iniciadas ainda na transição do século XIX para o século XX, teriam se consolidado, em Vitória, nesta década. Essas transformações, decerto, impactaram na imagem que a sociedade projetava da mulher capixaba. A segunda decisão refere-se à escolha da revista Vida Capichaba (1923-1957) como fonte, periódico de publicação quinzenal que circulou na Capital do Espírito Santo e no seu interior. Segundo Xavier (2008), foi o principal impresso do Estado na primeira metade do século XX, circulando entre 1923 e 1957. A Vida Capichaba inaugurou na sociedade local um novo espaço de circulação de ideias. A revista investia nos atrativos propiciados pelos recursos gráficos, como cores, imagens e papel de maior qualidade. Tais características tornavam a leitura mais amena e sedutora para os leitores da época. O sucesso/longevidade da Vida Capichaba baseou-se na capacidade de reunir vários dos atributos do estilo de vida moderno (RANGEL, 2011). O periódico era ilustrado com fotografias de adultos e crianças, festas sociais, concursos diversos, eventos escolares, cívicos e esportivos. As capas tinham traços estilizados e modernos; eram constituídas de fotografias com paisagens capixabas ou, então, reproduziam, na maioria das vezes, imagens de corpos femininos. A Vida Capichaba reunia o que havia de novidade no jornalismo e publicidade espíritossantense, constituindo-se em fonte de informação quanto aos valores da sociedade capixaba entre as décadas de 1920 a 1950 .

As prescrições endereçadas à mulher eram comuns na revista, estando espalhadas ao longo de cada edição ou, então, reunidas em três seções dedicadas a elas: "A Eterna Vaidade", "Feminea" e "Elegância feminina". As mulheres capixabas compunham o público leitor desse periódico. Por isso, colunas como as citadas eram dedicadas à redação de temas considerados de interesse do público feminino. A cronista Ilza Dessaune tratava, na seção "Feminea", de assuntos de moda, conselhos de conduta e relatava os eventos ocorridos em Vitória. A seção "A Eterna vaidade" era "recheada" de 
dicas de comportamento e vestuário, direcionadas a ambos os sexos. Na página "Elegância Feminina", observamos as últimas novidades na moda e alguma publicidade direcionada ao vestuário ${ }^{1}$.

A análise das imagens femininas disseminadas em periódicos se constitui como estratégia de trabalho bastante utilizada; no campo da Educação Física, um dos trabalhos mais importantes (por seu pioneirismo) é o de Goellner (2003). Em Vitória, destacamos a pesquisa de Xavier (2008) e de Rangel (2011), as quais discutem, respectivamente, as relações de poder e o feminismo presentes nas páginas da Vida Capichaba.

Organizamos o artigo em três tópicos. No primeiro, descrevemos os valores culturais e morais esperados das mulheres, em que se enalteciam as imagens do sexo maternal, frágil e belo. No segundo, narramos como a moda (esportiva) foi importante para desconstruir o "dever ser" feminino vinculado à maternidade e à fragilidade do "belo sexo", introduzindo a imagem de uma mulher moderna, atenta aos novos ideais da moda e da prática esportiva. Nas considerações finais, apontamos a presença de uma dualidade dos discursos direcionados à mulher e a importância do esporte na construção de um novo corpo feminino.

\section{ImAGENS dA MULHER NA REVISTA VidA CAPICHABA: ENTRE O CASA- MENTO, A MATERNIDADE, A FRAGILIDADE E A BELEZA}

Analisando as 112 edições publicadas entre os anos de 1940 e 1949, é possível concluir quais as imagens da mulher mais comuns na revista Vida Capichaba. Identificamos, por exemplo, a imagem feminina atrelada às tarefas relacionadas à família e a casa, pois seu lugar não seria o espaço público, mas, sim, os deveres privados, do lar. Nessas circunstâncias, também verificada em outros periódicos da mesma época (BASSANEZI, 1996; GOELLNER, 2003), a revista buscava ensinar as leitoras a cuidar da casa e a criar um "ambiente de felicidade ao lar", já que a dona-de-casa perfeita

\footnotetext{
'Não identificamos a autoria das seções "A Eterna Vaidade" e "Elegância Feminina".
} 
era o modelo de boa educação, tornando-se objeto de interesse dos homens e obsessão para as mulheres (PERROT, 2008). Muitos anúncios da revista retratavam a importância da mulher para a construção de uma família feliz. Por exemplo, em uma nota publicada em março de 1941, dizia-se que seria distribuído gratuitamente às assinantes da revista um manual que as ensinaria a fazer belos bordados e que, uma vez efetuados, dariam aos lares um ambiente de felicidade:

Brevemente, iremos distribuir gratuitamente as assinantes desta revista a esplendida e útil publicação, 'riscos e bordados do mensageiro do lar', como suplemento feminino, contendo em cada número, belos e numerosos modelos de bordados e um grande mapa de riscos em tamanhos naturais, além de várias seções que alegrarão nossas leitoras, e cujos modelos uma vez executados, darão aos lares um ambiente de felicidade. Dessa forma 'O mensageiro do lar' institui a Rêde Jornalística Nacional (R. J. N) contribuindo poderosamente em prol da unidade da família brasileira (VIDA CAPICHABA, 1941, s/p) ${ }^{2}$.

O ideal feminino estava, primordialmente, ligado ao casamento; a revista Vida Capichaba veiculava essa norma, já que a constituição da família era função primordial da mulher e "o casamento seria sua grande realização" (XAVIER, 2008). Rangel (2011) ratifica essa conclusão, ao apontar que o discurso predominante na Vida Capichaba era o da mulher como "anjo do lar", tendo como função o casamento e a maternidade. Enquanto mãe e esposa, a mulher era colocada como a grande responsável pelo funcionamento e bom andamento do lar. As mulheres eram exaltadas pelo seu papel de esposa, donas de casa e "mães de família" (RANGEL, 2011).

Relatos de noivados e casamentos eram constantes nas páginas da revista (Figura 1): a Coluna "Alfinetadas" sempre trazia os enlaces anunciados na sociedade capixaba, como demonstrado nesse breve

${ }^{2}$ Manteve-se a originalidade da escrita.

Movimento, Porto Alegre, v. 19, n. 02, p. 227-249, abr/jun de 2013. 
trecho: "A funcionária moreninha da prefeitura fez-se noiva... Parabéns" (VIDA CAPICHABA, s/p, 1942). Como também no poema de Paulo Setubal, publicado em fevereiro de 1945:

És noiva...Em breve há de raiar o dia, Festivo, azul, vibrante de alegria, Que te sorri num céu de rosciclér, Irás à igreja. E num altar formoso, Branca de anseio, trêmula de gozo, Verás florir teu sonho de mulher (VIDA CAPICHABA, s/p, 1945).

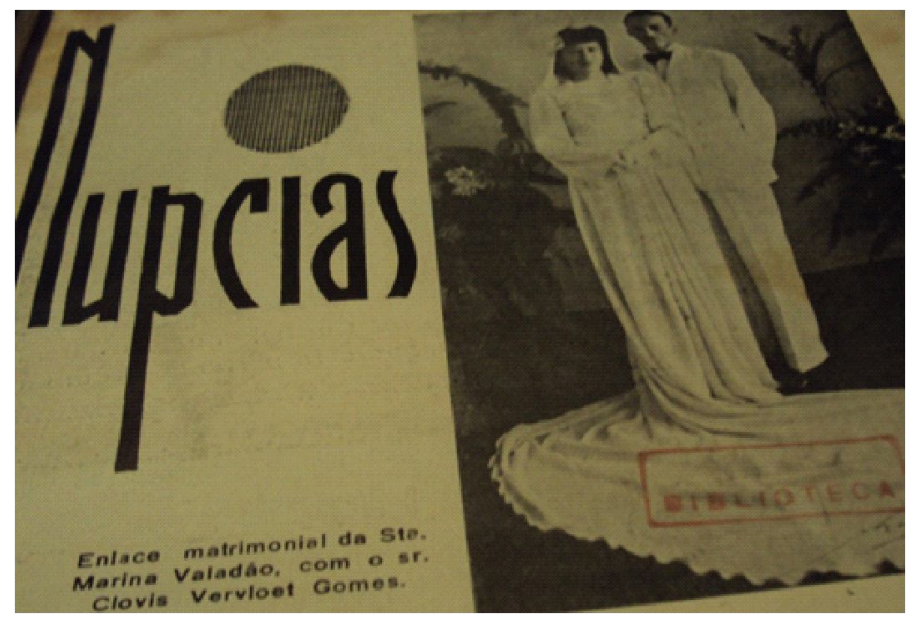

Figura 1. Anúncio de enlace matrimonial

Fonte: VIDA CAPICHABA, 15 de julho de 1941.

Ao mesmo tempo em que sua imagem estava associada ao ambiente privado do lar (boa mãe, boa esposa), a mulher era portadora de uma saúde frágil, necessitando, assim, de cuidados específicos para os males que as assolavam. Na revista Vida Capichaba, esse ideal de fragilidade feminina se fez bastante presente. A delicadeza da mulher era declamada em poemas que enalteciam seus encantos, sua doçura, passividade e feminilidade, como observamos no excerto a seguir:

As mulheres são adornos da sociedade. As flôres enfeites da natureza. Nas flores admiramos cores tão belas, que parece só podiam serem dadas por Deus: as mulheres apresentam cores tão lindas, que 
parecem creaturas do céu. As flôres são tão frágeis, que qualquer aragem as destroe; as mulheres são tão fracas que qualquer pesar as abale. As flores tornam o ar agradável com seus aromas divinos. As mulheres embelezam a vida com seu espírito. Qualquer inseto destroe a flor e a mata. Qualquer maldade aniquila a mulher e a perde. As flores adornam as nossas mesas. As mulheres enfeitam a nossa vida (VIDA CAPICHABA, 1946, s/p).

De acordo com Xavier (2008), o desenvolvimento dos estudos na área da ginecologia e obstetrícia reforçou os conceitos de que a mulher possuía uma saúde mais debilitada. Nessas circunstâncias, o uso de fortificantes e estimulantes era visto como auxiliares no fortalecimento do corpo das senhoras e contribuíam para manutenção de sua saúde, como ilustrado nas figuras abaixo:

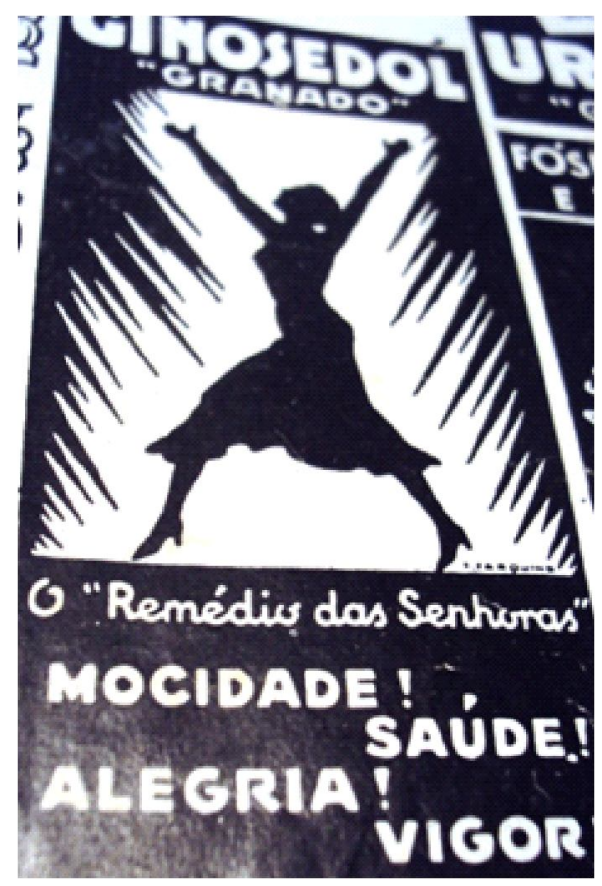

Figura 2. Anúncio de estimulantes e fortificantes

Fonte: VIDA CAPICHABA, 30 de janeiro de 1940.

Movimento, Porto Alegre, v. 19, n. 02, p. 227-249, abr/jun de 2013. 


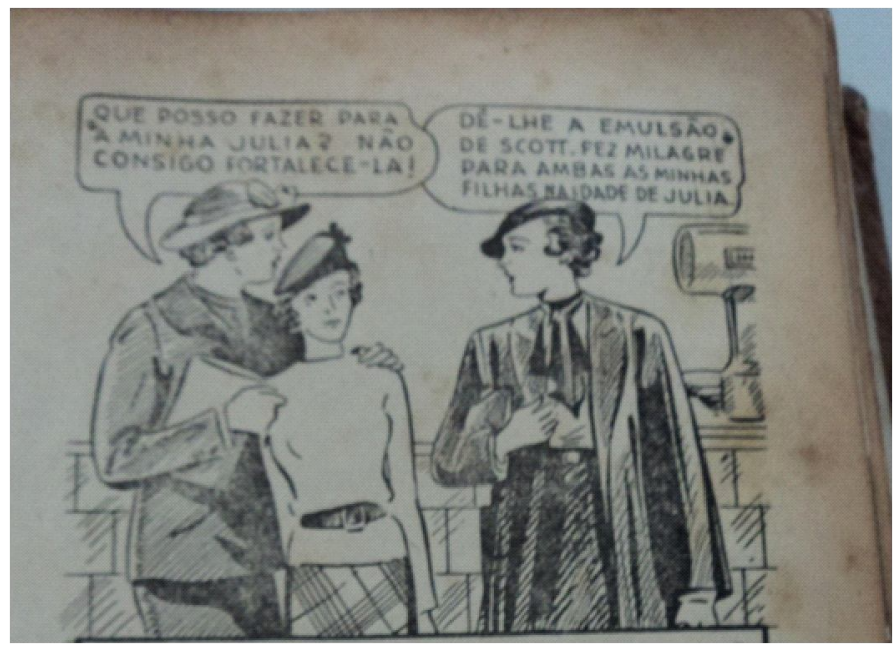

Figura 3. Anúncio de estimulantes e fortificantes

Fonte: VIDA CAPICHABA, 15 de abril de 1942.

Outro exemplo desse vínculo entre saúde e tônicos pode ser encontrado na propaganda do "Regulador Gesteira", um elixir que diminuía os sofrimentos femininos e que proporcionava grandes melhoras para as mulheres:

Quando levar uma queda, um susto, ou tiver raivas, quando receber uma notícia má, que cause tristeza e aborrecimento, sempre que se sentir nervosa, triste, zangada e mal disposta lembre-se que certos órgãos internos das mulheres se congestionam e se inflamam com muita facilidade, bastando para isso um abalo forte, uma comoção violenta, um resfriamento ou alguma imprudência. Aos primeiros sintomas de congestão e inflamação destes importantes órgãos útero-ovarianos use Regulador Gesteira. Faça assim que evitará muitas doenças perigosas. Regulador Gesteira trata os padecimentos nervosos produzidos pelas moléstias do útero, peso no ventre, dores, cólicas e perturbações da menstruação, debilidade, palidez e tendência a hemorragia, provocadas pelos sofrimentos do útero, tristezas súbitas, palpitações, 
sensação de sufocação, tonturas, peso e dormência nas pernas, falta de ânimo para fazer qualquer trabalho e todas as perigosas alterações da saúde causadas pelas congestões e inflamações do útero. Regulador Gesteria evita e trata estas congestões e inflamações internas e as complicações provenientes destas inflamações (VIDA CAPICHABA,1943, s/ p).

A revista Vida Capichaba não veiculou apenas imagens femininas atreladas ao lar e à fragilidade de sua saúde, mas, também, associou essa imagem aos ideais de beleza. A revista exaltava a beleza feminina, de modo que várias matérias forneciam dicas sobre como realçá-la. Como ilustra matéria assinada por Denise Vedrune, a qual dizia que "[...] não há mulheres feias, há apenas mulheres que não sabem tirar partido do seu rosto" (VIDA CAPICHABA, 1946, $\mathrm{s} / \mathrm{p})$. Os discursos que referenciam a mulher como sendo o "belo sexo" (LIPOVETSKY, 2000), detentora do capital beleza, carregam consigo um imperativo: o de fazer-se bela (ALBINO; VAZ, 2005). A responsabilidade que a revista acarreta a mulher faz com que ser bela deixe de ser uma possibilidade e passe a ser um dever. $\mathrm{Na}$ passagem abaixo, isso é evidente. Nela, a revista destaca seu dever de ser bela, sedutora e feminina, um imperativo que se iniciava já na vida privada:

Sendo tão previdente e exigente quando se trata de passeios, você é sem dúvida muito mais diante de seus filhos e de seu marido. Vendo ao jantar, a correção de seu penteado, concluímos que foi refeito a tarde. Certamente não gostaria de almoçar com os seus, dando-lhes o espetáculo melancólico de uma beleza que não se cuida e que só realça os encantos para os passeios: use então um lenço, graciosamente amarrado para esconder grampos, laços e papelotes. Devemos ser sedutoras para a sociedade, mas o primeiro dever de uma mulher é mostrar encanto no lar e prodigalizá-lo àqueles que lhes são íntimos (VIDA CAPICHABA, 1946, s/p). 
O rosto toma um lugar importante nos cuidados com o corpo, no qual emergem estratégias para torná-lo cada vez mais belos. A revista, ao se colocar como parceria da mulher, a ajuda nessa tarefa imprescindível, dando-lhes conselhos sobre a maquiagem ideal para cada tipo de rosto, como:

Se você tem o rosto quadrado - Antes de mais nada você sabe que isso é um sinal de coragem e perseverança? Você deve portanto ter energia de sobra. Entregue uma parcela dessa grande qualidade em se tornar mais bonita. [...] Espalhe o rouge entre as orelhas e o queixo o que dará a sua face um bonito arredondado, não depile demais as sobrancelhas. Se você lhes der uma linha horizontal e muito fina acentuará mais ainda os traços quadrados do seu rosto. Dê-lhes uma fôrma curva (VIDA CAPICHABA, 1946, s/p).

Obviamente, os cabelos não poderiam ficar fora desse arsenal de cuidados:

Por Malou - O penteado ocupa um lugar de grande importância na elegância e encanto feminino [...] Assim, ao levantar-se, deverá pentear-se ou prender os cabelos numa rede de renda, a menos que prefira esconder $\mathrm{o}<<$ mise em plis $>>$ com um daqueles turbantes cujo segredo a parisiense conhece, dandolhes um cunho pessoal e que são usados tanto em casa, como nos passeios e saídas para compras (VIDA CAPICHABA, 1946, s/p).

Os cuidados femininos vão além da superfície; não basta fazer uma boa maquiagem ou um belo penteado. Com as novas descobertas médicas, a compreensão da pele como órgão permite às mulheres se preocupar com a saúde da cútis, o que contribui na manutenção de sua juventude:

É preferível prevenir, a ter que corrigir os defeitos da pele, que tanto enfeiam o rosto. Rugol, usado diariamente em massagens, evita o apparecimento de cravos, espinhas, sardas, manchas e rugas. Rugol, penetra até as camadas sub-cutaneas e fortalece os tecidos, impedindo que a pelle se torne flácida, sem viço, e que se formem rugas e pés de gallinhas. 
Rugolé a garantia de sua mocidade e da conservação da beleza de sua cútis (VIDA CAPICHABA, 1942, $\mathrm{s} / \mathrm{p})$.

As dicas das novidades da medicina estética, desse modo, "[...] sugerem à leitora que é possível ter um corpo semelhante aos das modelos, ou que a beleza que as 'estrelas' possuem é fruto do correto investimento (possíveis para todas) em seus corpos" (ALBINO; VAZ, 2005 , p. 215). De acordo com Lipovetsky (2000), neste período, o uso de cosmético é um imperativo de civilidade e a boa aparência se torna por vez dimensão essencial do feminino. A Vida Capichaba preenchia suas páginas com muitas imagens de rostos de mulheres jovens. Os gestos e costumes que buscaram uma fisionomia mais a moda revelam, também, as diversas nuanças do sonho de ser moderno e civilizado (SANT'ANNA, 1995). Como mostra uma fotografia do rosto da miss Espírito Santo de 1949, a qual, de acordo com a revista, merece homenagem devido aos "seus dotes físicos, de espírito e pela sua elegância" (VIDA CAPICHABA, 1949).

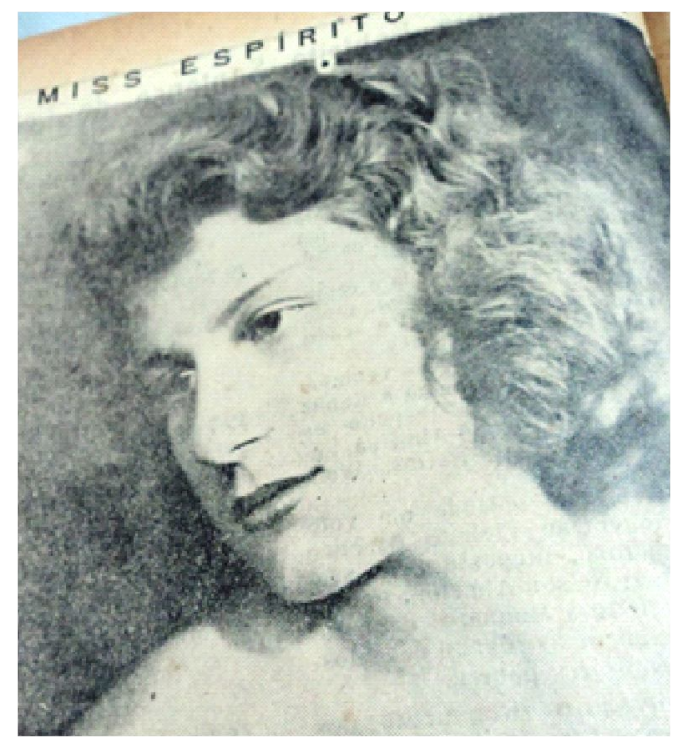

Figura 4. Fotografia do rosto da miss Espírito Santo de 1949

Fonte: VIDA CAPICHABA, agosto de 1949.

Movimento, Porto Alegre, v. 19, n. 02, p. 227-249, abr/jun de 2013. 
Trata-se, a partir de então, de uma mulher provida de informações e com um tipo de "licença" social para educar e dominar o seu corpo para a conquista da beleza. O que prevalece é a máxima de que todas podem ser bonitas, desde que invistam em si mesmas. A beleza feminina não é mais um privilégio da natureza, reservado a um pequeno número de mulheres, mas

O princípio de livre posse de si tornou ilegítima a cultura da aceitação do dado, valorizou a vontade de domínio soberano sobre a aparência a fez cair as antigas resistências à otimização da beleza. Ao esquema tradicional que define a beleza como intangível presente dos céus sucedeu o dispositivo da beleza passível de apropriação, expressão estética do princípio moderno de controle ilimitado do mundo (LIPOVETSKY, 2000, p. 163).

Ao mesmo tempo em que essas prescrições eram dirigidas às mulheres, foi possível identificar, nas páginas do impresso, discursos que contrariavam o dever ser feminino vinculado à maternidade e à fragilidade do "belo sexo". Nesse contexto, a moda, em especial a com inspiração esportiva, foi fundamental para introduzir, nas páginas de Vida Capichaba, outras imagens ou modos de se viver a feminilidade. São olhares que se diversificam e para os quais as imagens de mãe, dona de casa e frágil não retiram da mulher outras possibilidades de viver a sociedade e seu tempo. Vejamos isso no tópico a seguir.

\section{ImAGens dA MULher NA Vida CAPICHABA: AS MULHERES No RITMO DA MODA (ESPORTIVA)}

A moda no Brasil, até os meados do século XIX, se caracterizava por vestidos volumosos de cores sóbrias. Essa aparência pesada se vinculava a uma elite ainda muito ligada ao meio rural (DEL PRIORE, 2004; FEIJÃO, 2011). A fragilidade e a dependência da mulher desse tempo eram vistas em suas vestimentas. Trajes complicados, peças que encerravam o corpo em suas camadas, em seu peso e volume. Isso refletia "simbolicamente a falta de autonomia da mulher" (FEIJÃO, 2011). 
É a partir dos anos de 1920, com a simplificação do vestuário feminino, que a moda se torna mais acessível, pois é mais facilmente imitável (LIPOVETSKY, 1989). E revistas como a Vida Capichaba têm papel fundamental nessa acessibilidade, ao mostrar os modelos, ao dizer às cores que estão em alta e declarar a ausência de aparatos que passam, então, a se fazer presentes. Assim, o vestuário (a moda) é um ato significativo, capaz de "revelar" o indivíduo. Na interpretação de Soares (2010), "[...] a sua aparente futilidade, banalidade, superficialidade, efemeridade, indicam maneiras de viver, indicam pertencimento". A Vida Capichaba estava atenta às mudanças que vinham acontecendo; suas páginas destacam o uso de roupas como um ato de distinção, como símbolo de modernidade. $\mathrm{O}$ impresso estava cheio de imagens de jovens modelos portando o que se chamava, então, de "as modas modernas"; junto às imagens, havia sempre a descrição do modelo e dicas de como utilizá-lo. Uma matéria da página "Elegância Feminina", de 1940, diz que:

Estão em moda as blusas e mais do que nunca estiveram. Pode-se dizer que é uma das notas mais interessantes da actualidade. No guarda-roupa feminino cheio dellas, pelo encanto renovado, pela singeleza, pelo trabalho maravilhoso de $<<$ lingerie $>>$, essas prendas sugerem mil recursos a toillete, acompanhando <<tailleurs $>>$ os mais elegantes e fazendo parte do conjunto os mais singelos (VIDA CAPICHABA, 1940, s/p).

Feijão (2011) afirma que o uso do tailleur tornou-se muito comum nos passeios pela cidade. Tal vestimenta se caracterizava por um conjunto de saia e blusa/casaco diretamente inspirado no guardaroupa masculino, o que reforçava a ligação desse tipo de vestimenta com as atividades até então de domínio masculino, pois, neste período, as mulheres já estão "autorizadas" a extrapolar a esfera privada do lar. De acordo com Feijão (2011), elas trabalham, viajam e fazem compras. Esses são hábitos cosmopolitas, obviamente inspirados pelo anseio de ser moderno, sem, contudo, abandonar a singeleza e a leveza (Figura 5). 


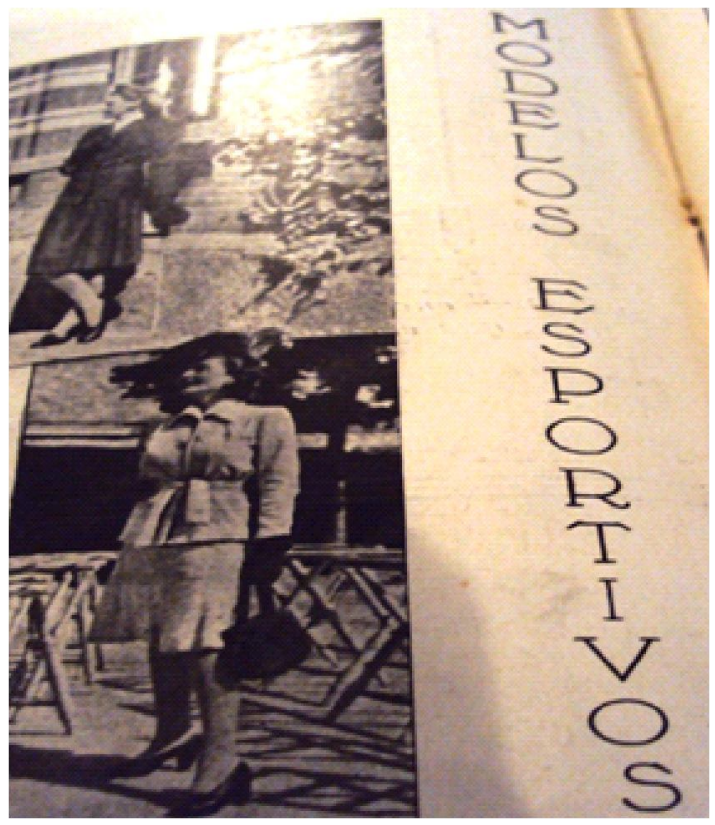

Figura 5. Hábitos cosmopolitas

Fonte: ELEGÂNCIA FEMININA. 15 de novembro 1943.

A moda dos cabelos à La garçonne, junto ao uso de tailleur, dava às jovens uma sensação real de mudança de época, de viverem em um período novo, mais liberal (PERROT, 2008). O cabelo é o sinal mais visível de feminilidade e o corte de cabelo corresponde à imagem de uma mulher moderna, detentora de uma nova feminilidade. As figuras 6 e 7 abaixo retratam o novo corte de cabelo, que costumeiramente era acompanhado de pequenos chapéus, permitindo maior comodidade junto a um desejo de leveza (PERROT, 2008). Os cabelos à La garçonne rompiam com as vastas cabeleiras de outrora, proporcionando às moças uma aparência assustadoramente masculina (SEVCENKO, 1992), trazendo a ideia de uma mulher mais combativa.

Figuras 6 e 7. Anúncio de tendências de cortes de cabelo femininos 


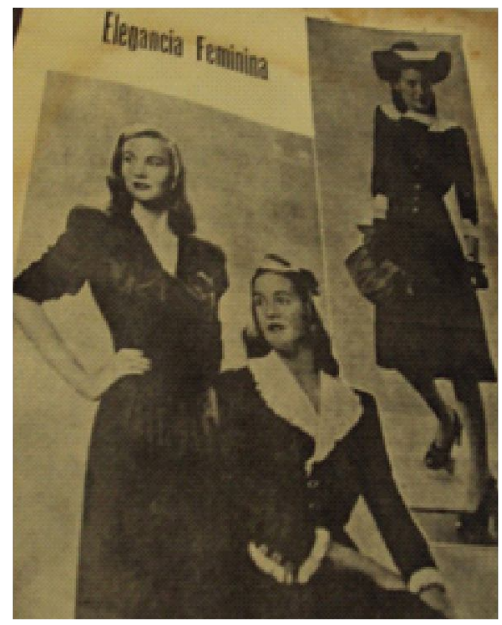

Fonte: ELEGÂNCIA FEMININA, 30 de maio de 1941 .

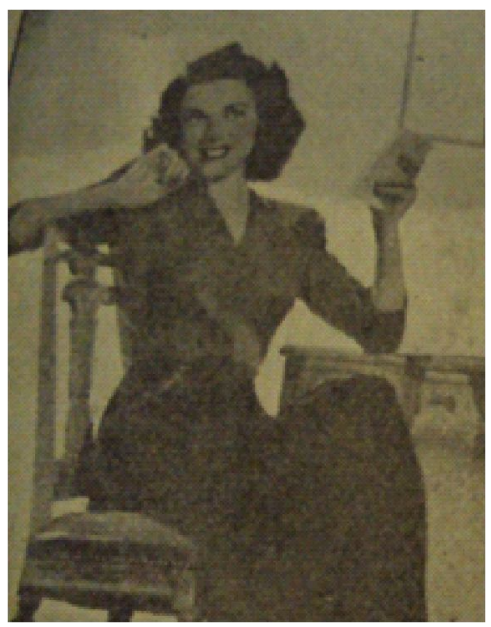

Fonte: ELEGÂNCIA FEMININA, 15 de setembro de 1943 .

Conforto e eficácia (SOARES, 2010) também fazem parte desse novo estilo de se vestir, sem abdicar, contudo da elegância:

Os vestidos de noite, cuja linha requer um destaque apropriado, conta também com essas blusas realizadas em tecidos de certo esplendor, para ceias e até para bailes. As combinações, neste sentido, são sempre sóbrias, para bellos effeitos. Assim fica linda, mais linda uma blusa de chiffon rosa pálido, decotada, inteiramente plissada, sem mangas, acompanhada de saia comprida, que pode ser negra de seda... Com a mesma saia outra blusa não terá menor beleza e será a interpretada em lamê, cor celeste e ouro, cujo decote seria alto e redondo e cujas mangas se armem em globo. Se for para ceia o completo é um pequeno bolero do mesmo panno da saia. Nas atividades desportivas, as blusas que se impõem são as cortadas em forma de colete e as de estilo <chemesier>. O material preferido para fazel-as varia entre os crepes e as sedas, com bolas ou listas (VIDA CAPICHABA,1940, s/p).

Nesse contexto, o esporte foi um fenômeno cultural que teve um papel de primeiro plano na revolução democrática do parecer 
feminino. A valorização dos esportes contribuiu para desencadear um processo de desnudação do corpo feminino (LIPOVETSKY, 1989; FEIJÃO, 2011, BARTHES, 1967). Posição semelhante possui Soares (2010, p. 119), para quem "Ao esconder e revelar voluntariamente partes escolhidas do corpo, elas [as roupas] acentuam a nudez, ou um corpo nu, como expressão de cultura. São as roupas que criam e destacam toda a erotização de um corpo que se desveste". Os modos de se vestir se modificam, as vestimentas encurtam, os decotes tornam-se abundantes, as blusas sem manga transmitem novas sensações e os tecidos propiciam leveza e transparência. De fato, os esportes tiveram grande influência no desuso das antigas anáguas e saias pesadas, ao propagar ideais de corpos mais maleáveis e dinâmicos. A moda esportiva vai possibilitar, assim, a expressão de uma nova sexualidade (GOELLNER, 2003). Vejamos isso na passagem a seguir, referente à prática dos patins entre as moças:

\footnotetext{
"Skaterina" é uma palavra nova americana que appareceu com o resurgir da moda de patins de rodas nos Estados-Unidos. "Skaterina (derivada de "skate" - patins) é o termo com que são denominadas as sainhas curtas tiornadas conhecidas no mundo inteiro pela encantadora Sonia Henje, e agora adoptadas por todas as "fans" de patinação. Foi justamente a adopção d'essas sainhas (e respectivos calções de seda) pelas freqüentadoras dos "rinks" de patinação que veio despertar um novo interesse pelo sport - pois que permitindo essa indumentária todos os movimentos e acrobacias, sem os entraves que os vestidos compridos apresentavam, isso veio tornar a patinação um divertimento ainda mais interessante para as "girls" - sem falar do bem mencionado facto que todas as pequenas gostam de exhibir uma perna bem feitinha[...] (VIDA CAPICHABA, 1940, s.p.).
}

A anunciada liberdade de movimento não estava restrita ao vestuário específico aas práticas esportivas e aos adeptos das atividades físicas, mas se ampliava na sociedade como um modelo e estilo de vida, pois nesse período triunfam os contornos físicos 
desembaraçados e uma maior liberdade de movimento (SOARES, 2010). Na página de moda da Vida Capichaba (1940, s/p), dizia-se que as mulheres capixabas se interessavam pelo estilo esportivo devido "[...] as rodas femininas capixabas serem dotadas de grande senso artístico". Estilo esse que já era comum às mulheres de todo o mundo:

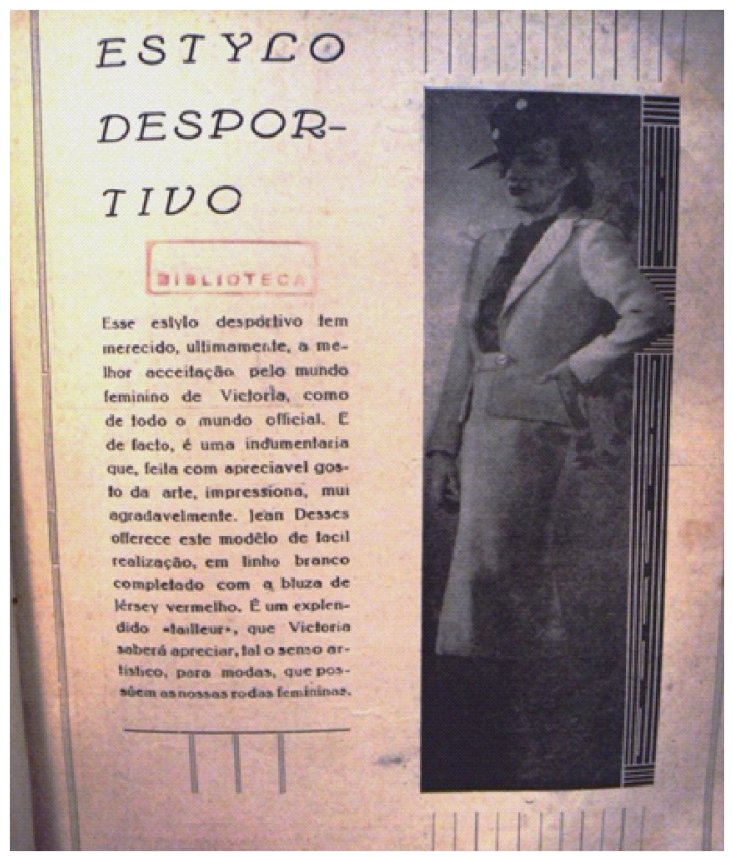

Figura 8. Estilo desportivo

Fonte: ESTYLO DESPORTIVO, 30 de maio de 1940.

André Ledoux, que vestia desde as mulheres que praticavam esportes náuticos até as que jogavam golfe, foi elogiado na Revista:

André Ledoux, grande costureiro de esportes de inverno, pensa hoje nas temporadas, nos week ends felizes. Veste a mulher que pratica esportes náuticos, a que escala montanhas ou que joga golf. Despe com originalidade a que vai à piscina ou à praia. Ver a coleção de Ledoux é evocar toda alegria do Sol Para o iate, calças, blusas e camisetas

Movimento, Porto Alegre, v. 19, n. 02, p. 227-249, abr/jun de 2013. 
inteiramente clássicas, o branco, o vermelho vivo, mas, sobretudo o azul. Eis uma encantadora saia baiadeira, amarela, marrom e branca, com uma blusa amarela; tirando-se a saia, vê-se um <short> justo e curto (os <shorts> tem este ano, as dimensões das roupas de banho). Um vestido para noite, chamado $<$ Palm Beach> deixa os ombros inteiramente descobertos, tendo de cada lado da cintura, uma <panier> inesperado. O tecido é de cor viva semeado de estrelas do mar (VIDA CAPICHABA, 1946, s/p).

Para Barthes (1967), as cores fortes na moda (como o "vermelho vivo", que aparece na vestimenta de André Ledoux) revelam independência, agressividade e liberdade, o que se relaciona com o comportamento das moças modernas, já que a moda do período realça a liberdade, "[...] repudiando tudo quanto é artificial e postiço, tudo que embaraça os movimentos e sufoca a natureza" [...] (SEVCENKO, 1992, p.52).

A moda esportiva implica, também, a produção de novos sentidos em relação aos espaços de lazer e de sociabilidade nas cidades. Paradigmático, a esse respeito, é o caso da praia e dos banhos de sol, uma vez que o bronzeamento tornou-se uma exigência de elegância e um novo ideal de beleza se constitui: o do corpo bronzeado. A moda do corpo bronzeado faz parte do estilo de vida de uma elite que valorizava as atividades ao ar livre, apropriando-se de modelos vividos na Europa e nos EUA (SOARES, 2010). A ida a praia, aos clubes para banhar-se nas piscinas, a prática do remo entre outras modalidades, se instituem como parte do cotidiano da vida moderna. Assim,

[...] falar de uma pele bronzeada, de uma outra tonalidade de pele, torna-se tema bastante instigante, pois, uma pele bronzeada não é, simplesmente, uma pele naturalmente escura e sim, resultado de um processo cuidadoso de exposição do corpo ao sol, ou às lâmpadas e cabines de bronzeamento (SOARES, 2010, p. 105).

Em matéria de 30 de setembro de 1948, a revista Vida Capichaba ensina e alerta quanto aos cuidados com os banhos de 
sol, não sem antes elogiar e relatar como são as banhistas que se aventuram nessa prática moderna:

Uma coisa que impressiona em nossas praias (sem falar das palpitações que nos causam as garotas em diáfanos maillots e em shorts shortíssimos) é o espetáculo de banhistas deitadas na areia sob um sol abrasador a se deixar torrar plàcidamente durante horas e horas (VIDA CAPICHABA, 1948, s/p).

Os esportes aquáticos também não ficaram alheios à moda esportiva, incorporando as modificações decorrentes dos novos valores corporais em tela. As mulheres capixabas estavam atentas a isso; como observamos na figura 9, a Srta. Sophia Reblin, a Miss do Clube de Regatas e Natação Álvares Cabral estampando a capa da Vida Capichaba de 30 de março de 1947. Vestir roupas específicas para a prática esportiva, ser miss de um clube esportivo e posar para a capa da revista mais importante da cidade na época constitui e atesta um lugar social diferenciado, confirmando a importância do esporte e das vestimentas na formação de novos valores femininos.

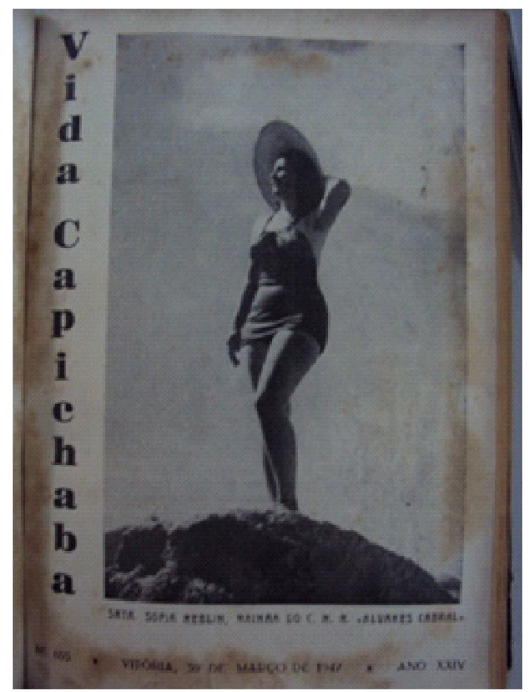

Figura 9- Capa da revista Vida Capichaba

Fonte: VIDA CAPICHABA, 30 de março de 1947.

Movimento, Porto Alegre, v. 19, n. 02, p. 227-249, abr/jun de 2013. 


\section{Considerações FINAIS}

Observamos, na análise da revista, como se reafirmaram ou se modificaram os imperativos na formação da mulher moderna, tendo como dispositivo de análise o vestuário e a moda. Em outras palavras, como se mantiveram ou se inovaram discursos sobre seu corpo.

Os discursos incitavam as mulheres a mostrar seu corpo, mas, também diziam que as mulheres aderir à modernidade sem deixar de preservar suas virtudes "naturalmente" femininas, ressaltando que elas não poderiam esquecer-se dos seus deveres e atribuições com a família. Identificamos, assim, que os discursos se entrelaçam, são notoriamente ambivalentes e ambos falam de um "dever ser" feminino. Um "dever ser" moral, constituído por um comportamento adequado, por valores tidos como destinados à mulher, como a fragilidade, a ternura e a aptidão para o matrimônio. Ou um "dever ser" que se faz presente na necessidade de se fazer bela e moderna, símbolo de civilidade e urbanidade. Aqui há um "equilíbrio de antagonismos" (LIPOVETSKY apud GOLDENBERG, 2006), pois a construção do corpo feminino é conservadora e subversiva, ao mesmo tempo. No momento em que a mulher começa a ter um grau de liberdade, ela continua a sofrer pressões sociais na ordem dos valores morais e sociais. Por um lado, se propicia maior gestualidade corporal, maior liberdade de movimentos; por outro, se exige mais cuidados corporais, já que agora o corpo está mais a mostra.

Graças a imprensa, as mulheres passaram a ser informadas sobre a "última novidade" em vestuário, podendo vestir-se na moda graças aos moldes, as imagens e as dicas de como usar determinado traje. Afinal, a Vida Capichaba estava atenta em veicular as ideias de modernidade, venerando o progresso, a civilidade e a tecnologia, influenciando novos estilos de vida.

Há uma influência mútua entre as roupas do cotidiano, a prática esportiva e as roupas específicas para a prática do esporte. Junto a isso aparece o desejo (e a obrigação) de beleza, eficiência, flexibilidade, agilidade e as mulheres não devem esquecer-se da elegância. Todas essas são características tipicamente modernas e 
que se manifestam no corpo. Essas sensibilidades moldaram um novo corpo feminino, corpo esse que foi o lugar no qual esse conjunto de técnicas e pedagogias foi posta em ação. 


Images of women in the magazine vida
capichaba (1940-1949)
Abstract: This text examines images of women in
Vida Capichaba, a biweekly magazine in circulation in
the State of Espírito Santo (Brazil) between the
decades of 1920 and 1950 . It focuses on the issues
published between 1940 and 1949, analyzing the social
imperatives aimed at the instruction of women in Espírito
Santo. It concludes that these imperatives were
ambivalent (both conservative and subversive), with
women-related sports and fashion playing a major
role in the construction of new images and meanings
of the feminine.
Keywords: Woman. Fashion. Sports.

Imágenes de la mujer en la revista vida
capichaba (1940-1949)
Resumen: Investiga imágenes de la mujer en la revista
Vida Capichaba, publicación quincenal que circuló, en
el Estado de Espírito Santo, entre las décadas de 1920
y 1950 . El estudio se centra en las ediciones publicadas
entre los años de 1940 hasta 1949. Analiza los
imperativos sociales destinados a la formación de la
mujer capixaba. Concluye que esos imperativos eran
ambivalentes (al mismo tiempo conservadores y
subversivos), siendo que la práctica deportiva y la
moda estaban asociadas a ella como papel importante
en la construcción de nuevas imágenes y sentidos
del femenino.
Palabras clave: Mujer. Moda. Deportes.

\section{REFERÊNCIAS}

ALBINO, B. S.; VAZ, A. F. "Mulher, como deves ser": Um Estudo sobre a Educação do Corpo Feminino no Jornal Dia e Noite (1940-1941). Temas e Matizes, Cascavel, Unioeste, v. 4, n. 7, p. 63-74, 2005.

A'S NOSSAS Leitoras. Vida Capichaba, Vitória, v. 19, n. 520, 15 de mar. 1941.

BARTHES, R. Sistema da Moda. Lisboa: Edições 70, 1967.

BASSANEZI. C. Virando as Páginas, Revendo as Mulheres: revistas femininas e relações homem-mulher (1945-1964). Rio de Janeiro: Civilização Brasileira, 1996.

CAPA da revista. Vida Capichaba, Vitória, v. 24, n. 655, 30 de mar. 1947.

CUIDADO com os banhos de sol. Vida Capichaba, Vitória, v.25, n. 679, 30 de set. 1948. 
DEL PRIORE, M.(org). História das mulheres no Brasil. Rio de Janeiro: Contexto, 2004.

ELEGÂNCIA feminina. Vida Capichaba, Vitória, v. 18, n. 502, 30 de maio 1940.

ELEGÂNCIA feminina. Vida Capichaba, Vitória, v. 21, n. 582, 15 de nov. de 1943.

ELEGÂNCIA feminina. Vida Capichaba, Vitória, v. 19, n. 525, 30 de maio 1941.

ELEGÂNCIA feminina. Vida Capichaba, Vitória, v. 21, n. 578, 15 de set. 1943.

ESTYLO desportivo. Vida Capichaba. Vitória, v. 18, n. 502, 30 de maio 1940.

FEIJÃO. R. Moda e Modernidade na belle époque carioca. São Paulo: Estação das Letras e Cores, 2011.

GOELLNER, S. V. Bela, Maternal e Feminina: Imagens da Mulher na Revista Educação Physica. ljuí: Unijuí. 2003.

GOELLNER, S. V.. As mulheres fortes são aquelas que fazem uma raça forte: esporte, eugenia e nacionalismo no Brasil no início do século XX. Revista de História do Esporte, Rio de Janeiro, v. 1, n. 1, p. 1-28. jun. 2008.

GOLDENBERG, M. O corpo como capital: para compreender a cultura brasileira. Arquivos em movimento, Rio de Janeiro, v. 2, n. 2, p. 115-123, jul/dez., 2006.

LAVER, J. A roupa e a moda: uma história concisa. São Paulo: Cia das Letras, 1989.

LIPOVETSKY, G. O império do efêmero: a moda e seu destino nas sociedades modernas. São Paulo: Cia das Letras, 1989.

LIPOVETSKY, G. A terceira mulher: permanência e revolução do feminino. São Paulo: Companhia das Letras, 2000.

PARA a mulher capichaba. Vida Capichaba, Vitória, v. 22, n.663, 30 de mar., 1946.

PERROT, M. Minha História das Mulheres. São Paulo: Contexto, 2008.

OS PRAZERES do sol. Vida Capichaba, Vitória, v. 24, n. 648, 30 de nov.1946.

RANGEL, L. A. S. "Feminismo ideal e sadio": os discursos feministas nas vozes das mulheres intelectuais capixabas. 2011. Dissertação (Mestrado em História) - Programa de Pós-Graduação em História, Universidade Federal do Espírito Santo, Vitória, 2011.

SANT'ANNA, D, B. Cuidados de Si e Embelezamento Feminino: Fragmentos para uma história do corpo no Brasil. In: Políticas do Corpo. São Paulo: Estação Liberdade, 1995.

SEVCENKO, N. Orfeu extático na metrópole: São Paulo, sociedade e cultura nos frementes anos 20. São Paulo: Companhia das Letras, 1992. 
SOARES, C.L. As roupas nas práticas corporais e esportivas: a educação do corpo entre o conforto, a elegância e a eficiência (1920-1940). 2010. Tese de livre docência. Universidade Estadual de Campinas, Campinas, 2010.

VIDA CAPICHABA. Vitória, v. 19, n. 528, 15 de jul. 1941.

VIDA CAPICHABA. Vitória, v. 19, n. 545, 15 de abr. 1942.

VIDA CAPICHABA. Vitória, v. 19, n. 545, 15 de abr. 1942.

VIDA CAPICHABA. Vitória, v. 19, n. 542, 28 de fev. 1942.

VIDA CAPICHABA. Vitória, v.18, n. 493, 30 de jan. 1940.

VIDA CAPICHABA. Vitória, v. 20, n. 567, 30 de mar. 1943.

VIDA CAPICHABA. Vitória, v. 19, n. 542, 28 de fev. 1942.

VIDA CAPICHABA. Vitória, v. 27, n. 690, ago. 1949.

VIDA CAPICHABA. Vitória, v. 18, n. 494, 30 de jan. 1940.

VIDA CAPICHABA. Vitória, v. 18, n. 510,30 de set. 1940.

XAVIER, K. R. L. Mulher e Poder nas Páginas da Revista Vida Capichaba. (1923-1945). 2008. Dissertação (Mestrado em História) - Programa de PósGraduação em História, Universidade Federal do Espírito Santo, Vitória, 2008.

Financiamento: Edital MCT/CNPq 14/2009

Edital FAPES Nº 012/2011 - UNIVERSAL

Endereço para correspondência:

Cecília Nunes da Silva

Rua Afonso Cláudio, n. 164, Santa Inês.

Vila Velha - ES

CEP: $29108-200$

Recebido em: 26.09.2012

Aprovado em: 26.02.2013 